Анна Викторовна Петрова

(Москва, Российская Федерация) netochka-1@yandex.ru

\title{
Ф. М. Достоевский в документах рукописного фонда Государственного музея истории российской дитературы имени В. И. Даля*
}

Аннотация. В статье представлен обзор материалов о Ф. М. Достоевском из собрания его
супруги А. Г. Достоевской, переданных ею в мае 1906 г. в Москву на вечное хранение
и с середины ХХ века частично находящихся в рукописном отделе Государственного
музея истории российской литературы им. В. И. Даля (Государственного литературного
музея). Эти документы можно разделить на визуальные, предназначенные для просмотра
посетителями музея, и текстовые. Наибольшей ценностью обладают письма Ф. М. До-
стоевского и другие визуальные материалы, связанные с главными событиями жизни
писателя. Они сохранили память о его личности и судьбе. Текстовые документы фонда
системно и достаточно полно представляют газетную критику Ф. М. Достоевском в пе-
риод с 1846 по 1914 г. и выборочно, на уровне отдельных статей - историю изучения
биографии и творчества писателя в ХХ в. Рукописный фонд Достоевского дополняется
богатой коллекцией изофонда, основу которой составляют фотографии, портреты Ф. М. До--
стоевского и лиц из его окружения, собранные А. Г. Достоевской. Ключевые слова: Ф. М. Достоевский, коллекция А. Г. Достоевской, Государственный музей истории российской литературы имени В. И. Даля, рукописные материалы, источниковедение

Об авторе: Петрова Анна Викторовна - кандидат филологических наук, ведущий научный сотрудник отдела «Музей-квартира Ф. М. Достоевского», Государственный музей истории российской литературы им. В. И. Даля (Государственный литературный музей) (103030, Российская Федерация, г. Москва, ул. Достоевского, д. 2)

Дата поступления: 18.04.2019

Дата публикации: 30.06 .2019

Для цитирования: Петрова А. В. Ф. М. Достоевский в документах рукописного фонда Государственного музея истории российской литературы имени В. И. Даля // Неизвестный Достоевский. — 2019. — № 2. - C. 40-55. DOI: 10.15393/j10.art.2019.4101

И сторически сложилось, что фонд Ф. М. Достоевского Государственного музея истории российской литературы имени В. И. Даля (Государственного литературного музея ${ }^{1)}$ ), является, наряду с рукописными отделами ИРЛИ РАН (Пушкинский Дом), РГБ, РНБ и РГАЛИ, одним из самых обширных и уникальных хранилищ докуменов, книг, фотографий, портретов, меморий, предметов мебели и быта, скульптур ${ }^{1}$. По словам Г. Б. Пономаревой, заведующей московского Музея-квартиры Достоевского в 1983-2017 гг., по количеству хранящихся в музее реликвий писателя этому фонду «нет равных в мире» [Пономарева: 102]. Все материалы в силу своей разнородности распределены по разным отделам музейного хранения и находятся в рукописном, книжном, изобразительном фондах, фонде декоративно-прикладного искусства, мебели, скульптуры и нумизматики.

1) Далее в тексте - ГЯМ.

(C) А. В. Петрова, 2019 
Коллекция фонда Ф. М. Достоевского на протяжении XX в. регулярно пополнялась и на сегодня насчитывает около 8 тысяч материалов, поступивших от потомков писателя, разных деятелей культуры и науки, сотрудников архивных и госучреждений, отдельных дарителей и исследователей его биографии и творчества. В основу фонда ГЛМ положена коллекция материалов, собранных А. Г. Достоевской, которую она с конца 1880-х гг. пересылала в Императорский Российский Исторический музей имени императора Александра III² $^{2}$ Здесь для них была отведена одна из башен здания. Образовалась музейная комната, которая называлась вначале «Отделом Достоевского», а в мае 1906 г., согласно воспоминаниям ее основательницы, получила название «Музея памяти Ф. М. Достоевского» [Достоевская: 560-567]. Вдова писателя продолжала пополнять «Музей памяти» до последних дней своей жизни: это подтверждается тем, что в деле о передаче архива Ф. М. Достоевского в Императорский Российский исторический музей перечислены 36 документов, поступивших от нее в период с января 1899 по ноябрь 1917 г. ${ }^{3}$

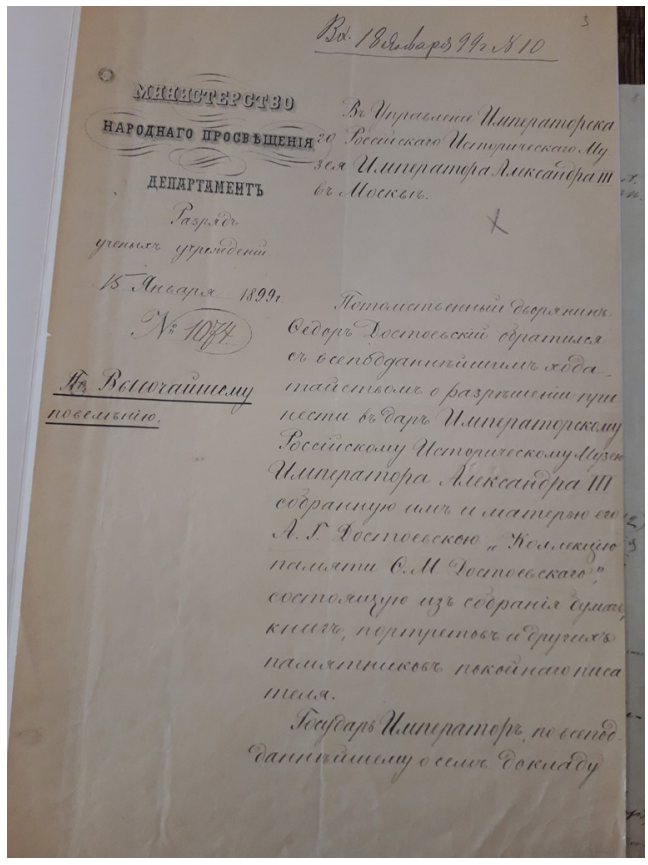

Илл. 1. Разрешение на передачу «Коллекции памяти Ф. М. Достоевского» в дар Историческому музею.

ОРФ ГЛМ. Ф. 81. Оп. 2. Ед. хр. 128. Л. 3

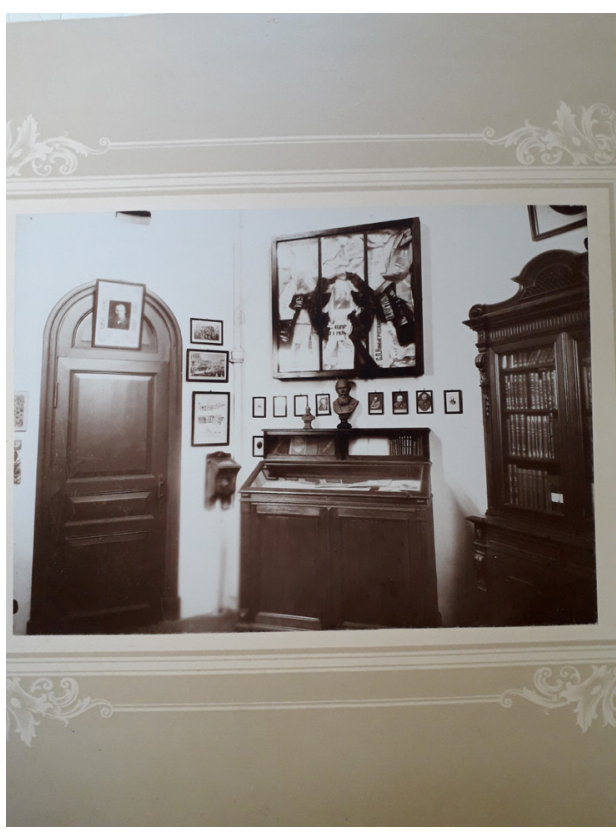

Илл. 2. Комната Ф. М. Достоевского в Историческом музее. Интерьер. Ателье Р. Ю. Тиле. 1901. Москва. Из собрания А. Г. Достоевской. Изофонд ГЛМ 
Один из документов процедуры передачи сыном Федором Федоровичем, как основным наследником, «коллекции памяти Ф. М. Достоевского» датирован 15 января 1899 г. (см.: Илл. 1). Однако собрание в целом было передано Историческому музею на вечное хранение в мае 1906 г. [Достоевская: 567].

Передав около 5 тысяч материалов в Москву, А. Г. Достоевская тем самым определила город рождения и детства писателя в качестве главного хранителя его духовного и материального наследия. После закрытия комнаты памяти Ф. М. Достоевского в 1929 г. последовала непростая история передвижения собрания А. Г. Достоевской, включавшая неоднократные разделения документов по разным архивам. Основное собрание А. Г. Достоевской было определено на хранение в «Музей-квартиру Ф. М. Достоевского» (с 1940 г. вошла в состав ГЛМ), открывшуюся в 1928 г. в Москве. В 1930-е гг. первый директор московского музея и исследователь В. С. Нечаева переместила рукописное наследие Ф. М. Достоевского в Государственную библиотеку имени В. И. Ленина, оставив музею лишь малую часть документов.

Материалы поступали в фонд Ф. М. Достоевского рукописного отдела ГЛМ по отдельности и частями. Наиболее интенсивные поступления произошли в 1937-1938, 1960, 1962, 1976 гг. из Государственной публичной исторической библиотеки, где находилась часть архива А. Г. Достоевской. Следует отметить, что к середине 1970-х гг. фонд практически сформировался. Он включает 293 единицы хранения на 6507 листах, представленные в двух описях (оп. 1, 2). Есть материалы на английском, немецком, французском, итальянском, сербском, китайском, японском языках, но большая часть имеющихся дел - на русском языке. Хронологические рамки фонда: 1750-2003 гг.

Документы фонда Ф. М. Достоевского в рукописном отделе ГЛМ собраны и включены в хранение с учетом специфики музейного дела, где важен не только рассказ и сведения о том или ином событии и явлении, но и показ, представление события в документе. Поэтому рукописный фонд включает много документов, ориентированных на зрительное, «быстрое» восприятие и предназначенных не столько для чтения, сколько для просмотра. Эта особенность дает возможность разделить все единицы хранения на визуальные материаль и на текстовые документы в рукописном или печатном видах.

Большинство визуальных материалов имеют нестандартный формат и либо сильно преуменьшают размер тетрадного листа, либо намного превышают его. Они содержат сведения локального, контекстуального характера и, скорее, указывают на то или иное событие, чем рассказывают о нем. Часть дел в этой группе объемом 1-2 листа форматом А3 (большой формат), либо А6 (малый формат). Содержащиеся в них сведения одновременно являются достоверной и объективной «книгой памяти», которая актуализирует связь прошлого с настоящим, приобщает к жизни писателя.

В фонде Ф. М. Достоевского находится пять писем писателя, все они неоднократно публиковались, прокомментированы, входят в полные собрания сочинений и в отдельные издания писем. Самое раннее из них, от 12 ноября 
1859 г., адресовано В. М. Карепиной․ В нем Достоевский уведомляет сестру о своем возвращении из Москвы в Тверь и высказывает желание приехать в Москву снова на более долгий срок, чтобы увидеться с ней и с семьей Веры, познакомить их со своей женой, а также уладить литературные дела.

К эпистолярному наследию Достоевского, хранящемуся в ГЛМ, относятся и короткие записки Н. Н. Страхову от 27 сентября 1873 г. ${ }^{5}$ насчет «Гражданина» и метранпажу типографии М. А. Александрову (от 30 августа 1876 г.) ${ }^{6}$ о высылке ему 5-й главы «Дневника писателя» (июль - август 1876 г.).

Два письма связаны с романом «Братья Карамазовы». В письме от 7 июня 1876 г. В. А. Алексееву, солисту оркестра Мариинского театра, Достоевский излагает свой взгляд на тему «камни и хлеба» и делает вывод о том, что, преодолевая первое искушение "хлебом», Христос тем самым утверждает в человеке преобладание высшей, духовной природы над низшей, животной. Другое письмо Ф. М. Достоевского представляет собой отклик-ответ от 19 декабря 1880 г. на известное письмо врача А. Ф. Благонравова, хранящееся в ОР РГБ.

Еще три письма Ф. М. Достоевского представлены в фонде Х. Д. Алчевской рукописного отдела ГЛМ. Они датированы 1876 г. и обращены к харьковской общественной деятельнице Х. Д. Алчевской, с которой Ф. М. Достоевский сначала вступил в переписку как с «сочувствующим ему читателем» ${ }^{7}$ и затем уже познакомился лично. В письме от 9 апреля 1876 г. ${ }^{8}$ Ф. М. Достоевский передает своей корреспондентке слова воодушевления, а также, отвечая на ее замечания по поводу «Дневника писателя», подробно обосновывает необходимость художника быть приверженным текущей действительности. В письмах Ф. М. Достоевского от 29 мая и от 1 июня 1876 г. ${ }^{9}$ проявляется сердечность и участие семьи Достоевских к Х. Д. Алчевской во время ее пребывания в С.-Петербурге.

В фонде М. А. Александрова хранятся две записки Ф. М. Достоевского ${ }^{10}$ о корректуре «Дневника писателя» $(1873,1877)$, датированные и комментированные А. Г. Достоевской. Все представленные в рукописном отделе ГЛМ письма Ф. М. Достоевского являются оригиналами, за исключением письма В. А. Алексееву, которое поступило в 1962 г. в виде копии, сделанной Г. И. Чулковым, с его же примечаниями (машинопись). Автограф этого письма, к сожалению, не найден, необходимы его поиски. По словам первого публикатора документа Ф. Ф. Бережкова (издавшего его под псевдонимом «Ф. Побединский», образованным от матронима), это письмо «принадлежит к числу самых значительных по содержанию писем Д<остоев>ского», так как в нем представлена «основа будущей истории создания глубочайшего из его творений» - романа «Братья Карамазовы» [Побединский: 199, 201].

К визуальным материалам отнесем также официальные документы $Ф$. М. Достоевского, описывающие его отношения с государством и общественными организациями. Прежде всего, следует отметить так называемую «черную папку» А. Г. Достоевской, обнаруженную в сейфе Исторической 
библиотеки Г. Ф. Коган, заведующей Музеем-квартирой Ф. М. Достоевского в Москве с 1955 по 1979 г. [Коган, 1994: 34], [Коган, 2001: 115-116]. Эта папка называется «Документы о прохождении службы и официальные бумаги Ф. М. Достоевского». Хранящиеся в ней 13 документов собраны и проаннотированы А. Г. Достоевской, расположены по хронологическому принципу, включают копии и оригиналы. В документах зафиксированы некоторые главные вехи жизненного пути Ф. М. Достоевского, и каждый из них отразил тот или иной виток его судьбы.

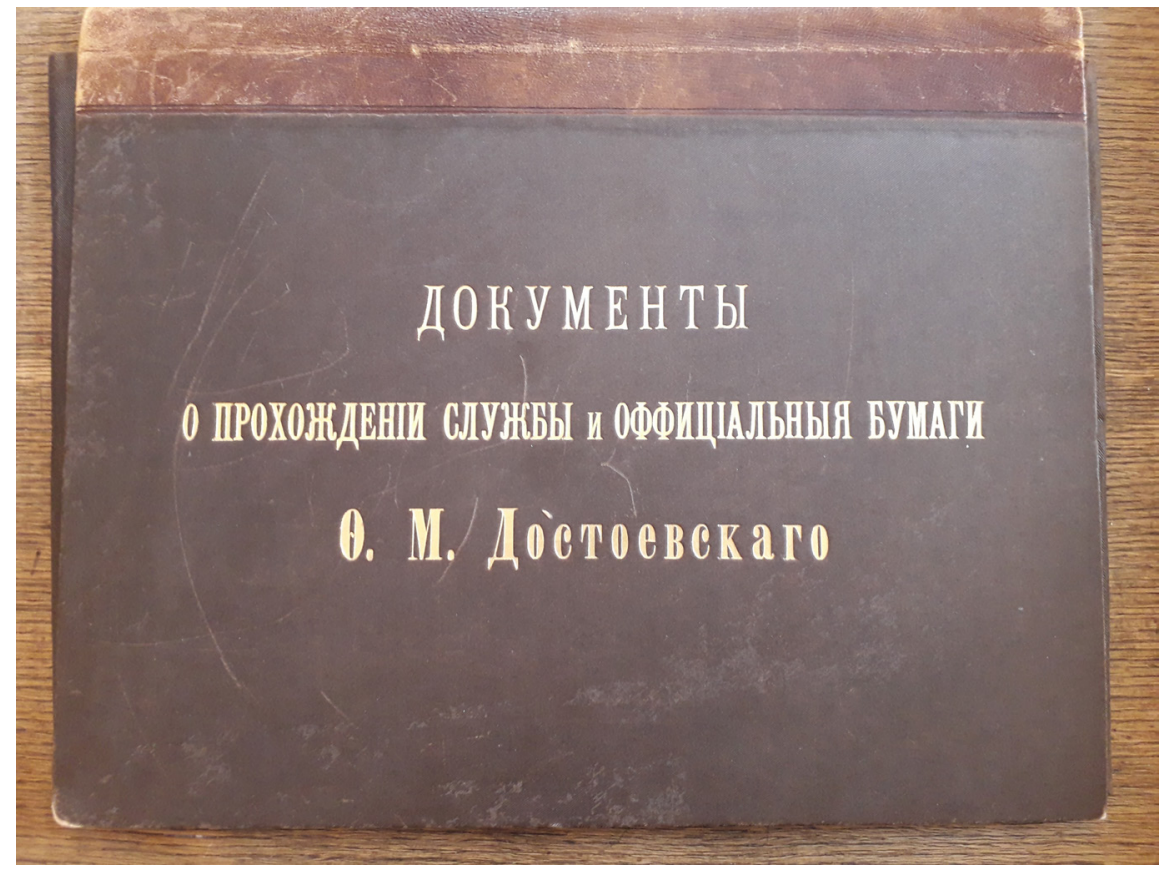

Илл. 3. Вид «черной папки». ОРФ ГЛМ. Ф. 81. Оп. 2. Ед. хр. 22

В «Выписке из кондуитного списка г. г. обер-офицерам Главного Инженерного училища за 1841 год ${ }^{11}$ Ф. М. Достоевский представлен как воспитанник, чье поведение отличается прилежанием, а познания - широтой изученных предметов. Следующий документ - «Формулярный список о службе и достоинстве состоящего в Главном Инженерном училище полевого инженера-прапорщика Достоевского» от 1 января 1842 г. $^{12}$

Судя по этим документам, Ф. М. Достоевский был образцовым учащимся, и ему открывался ровный и прямой путь к карьере военного. За этими материалами следует «Статейный список о государственных и политических преступниках, находящихся в Омской крепости в каторжной работе 2-го разряда» от 19 июня 1850 г. (копия, сделанная рукой А. Г. Достоевской) ${ }^{13}$. Здесь имя Достоевского стоит под номером («№ 7») и включено в один ряд 
с именами А. Мирецкого, И. Жоховского, П. Аристова, Ш. Токаржевского, И. Бугуславского, С. Дурова. В первой графе дано описание внешности преступника Ф. М. Достоевского по «типовым» признакам: «Лицо чистое белое, глаза серые, нос обыкновенный, волосы светло-русые, на лбу над левой бровью небольшой рубец» ${ }^{4}$. Далее в «черную папку» вложено письмо (оригинал) тверского губернатора П. Т. Баранова о том, что государь император изъявил свое «всемилостивейшее соизволение» на жительство Ф. М. Достоевского в С.-Петербурге (25 ноября 1859 г. $)^{15}$.

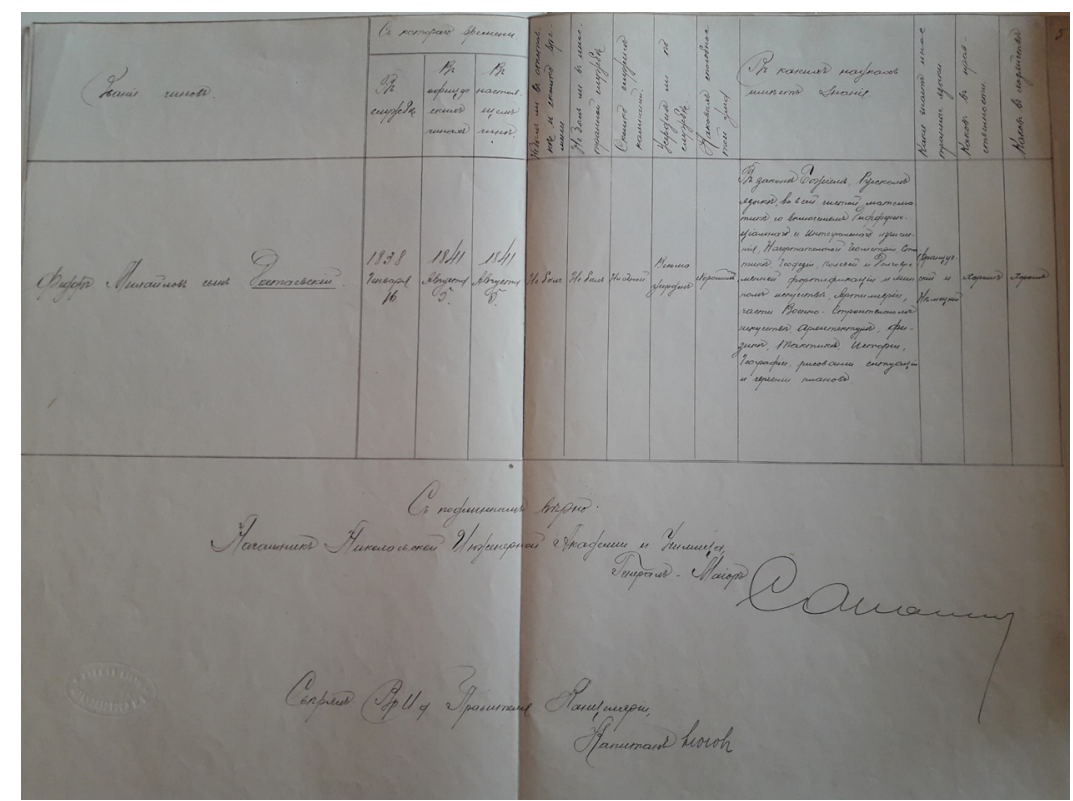

Илл. 4. Выписка из кондуитного списка Ф. М. Достоевского за 1841. ОРФ ГЛМ. Ф. 81. Оп. 2. Ед. хр. 22. Л. 5

Два следующих документа в папке демонстрируют твердость Ф. М. Достоевского в борьбе за свое слово. Сначала размещены документы, датированные 1873 г., - это «обвинительный акт по делу нарушения "Гражданином" цензурных правил» (писарская копия на бланке), повестка в суд (от 26 мая 1873 г. ${ }^{16}$, на котором писатель отказался признать себя виновным в цензурных нарушениях и, заплатив 25 руб. штрафа, два дня провел на гауптвахте 22-23 марта 1874 г. И другой документ - свидетельство 1877 г. «о разрешении Главного управления по делам печати на выход “Дневника писателя" Ф. М. Достоевского без предварительной цензуры» ${ }^{17}$ (копия на бланке).

Одним из значимых документов, хранящихся в этой папке, явился подлинный диплом Ф. М. Достоевского на звание члена-корреспондента Академии наук по Отделению русского языка и словесности ${ }^{18}$, куда писатель был избран 2 декабря 1877 г. [Коган, 1976], [Коган, 2001: 115-116]. 
Другая папка из серии «официальные документы» касается взаимоотношений Ф. М. Достоевского с Литературным фондом, куда он вступил в декабре 1859 г. ${ }^{19}$ Эти материалы напоминают о тяжбе писателя с кредиторами и кредитными учреждениями, отголоски которой продолжились даже после его смерти. К документам папки А. Г. Достоевская приложила «необходимое разъяснение» о том, что с середины 1880 -х гг. ей начали поступать анонимные письма о невыплате Ф. М. Достоевским задолженностей 1860-х гг. $(1860,1864)$ Литературному фонду. Получив все возможные документы, подтверждающие отсутствие долговых обязательств Фонду, А. Г. Достоевская разрешила сомнительную ситуацию.

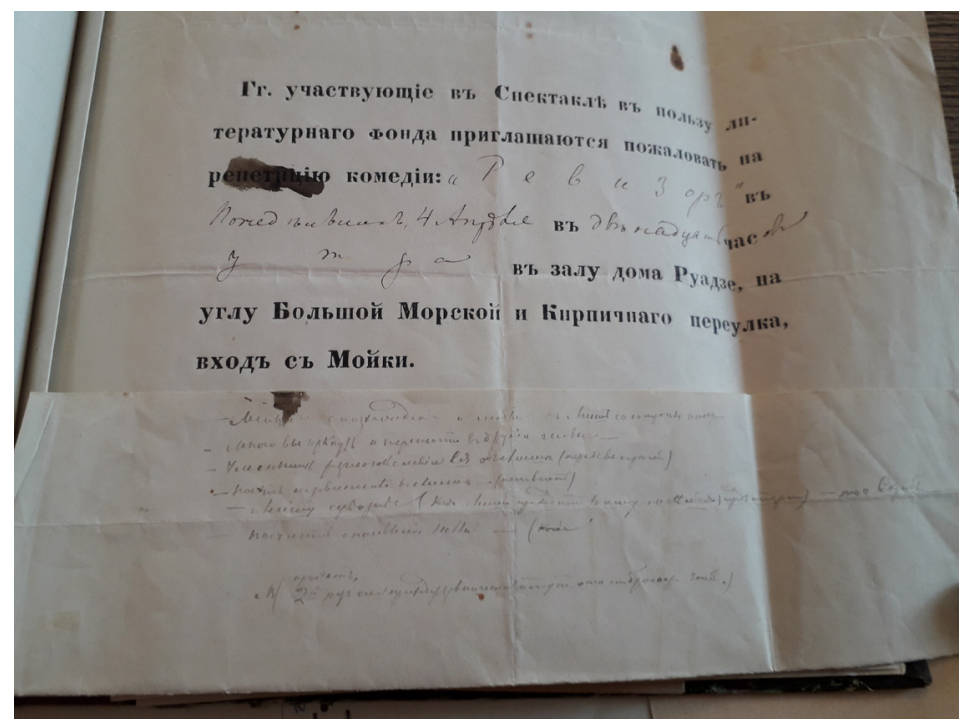

Илл. 5. Приглашение на спектакль «Ревизор» с черновыми записями Ф. М. Достоевского к роману «Униженные и оскорбленные» на обороте. ОРФ ГЛМ. Ф. 81. Оп. 2. Ед. хр. 27. Лл. 4-4 об.

Среди этих документов есть лист с приглашением на репетицию «Ревизора», устраиваемого Литературным фондом с участием Ф. М. Достоевского (роль почтмейстера). На нижнем крае оборота листа Г. Ф. Коган обнаружила черновую запись Ф. М. Достоевского к роману «Униженные и оскорбленные», над которым он работал в 1860-1861 гг. [Коган, 1973: 11-15]. Такая деталь наглядно передает сосредоточенность Ф. М. Достоевского на романе, напряженность работы его творческой мысли. На это указывал и сам Ф. М. Достоевский. В письме А. И. Шуберт от 3 мая 1860 г. он признавался: «...нахожусь вполне в лихорадочном положении. Всему причиною мой роман. Хочу написать хорошо, чувствую, что в нем есть поэзия, знаю, что от удачи его зависит вся моя литературная карьера. Месяца три придется теперь сидеть дни и ночи» ${ }^{20}$. После выхода в июле 1861 г. последней части «Униженных и оскорбленных» Ф. М. Достоевский в письме А. К. Каллаш 
от 16 августа 1861 г., очевидно еще находясь под впечатлением от работы над романом, сообщал: «Когда пишу что-нибудь, то даже думаю об том и когда обедаю, и когда сплю, и когда с кем-нибудь говорю»

Визуальные материалы фонда затрагивают не только официальные и общественно-деловые отношения Ф. М. Достоевского, но и касаются его участия в культурной жизни С.-Петербурга и Москвы. Это собранные А. Г. Достоевской почетные (а в некоторых случаях и именные) билеты на имя Ф. М. Достоевского для входа на литературные вечера и танцевальномузыкальные балы, присланные писателю в период с 1876 по 1880 гг. Эти вечера и балы устраивались в пользу малоимущих, «недостаточных студентов» Медико-хирургической академии, Института инженерных путей сообщений императора Александра I, слушательниц высших врачебных курсов и С.-Петербургского университета ${ }^{22}$. Сюда также входят программы и афиши литературных вечеров с участием самого писателя, они переплетены и вклеены А. Г. Достоевской в канцелярскую книгу⿰ ${ }^{23}$, к ним составлена аннотация, и они отражены в ее «Библиографическом указателе».

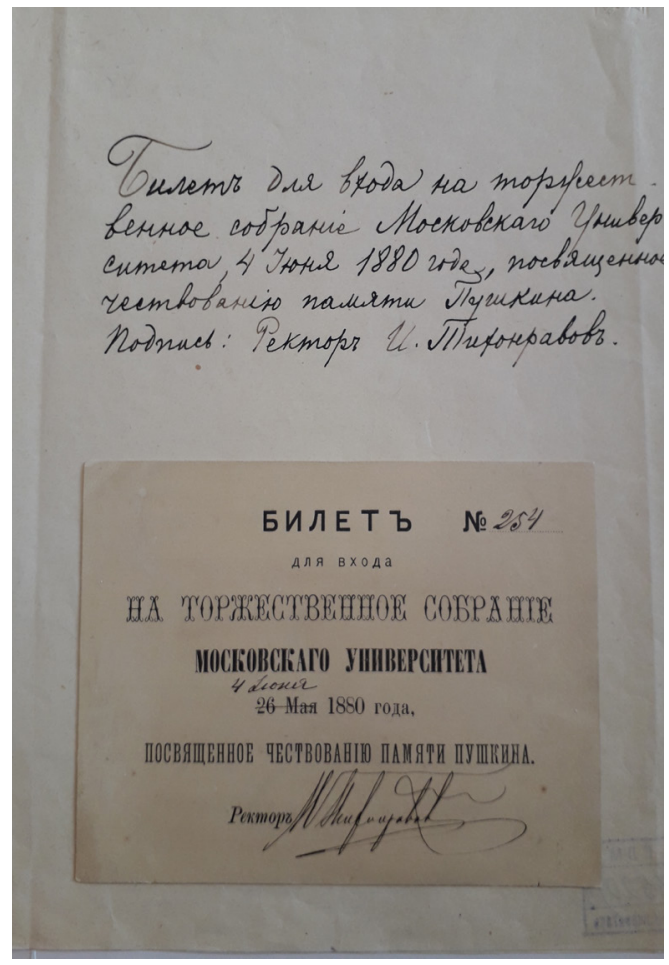

Илл. 6. Именной билет

Ф. М. Достоевского.

ОРФ ГЛМ. Ф. 81. Оп. 2. Ед. хр. 14

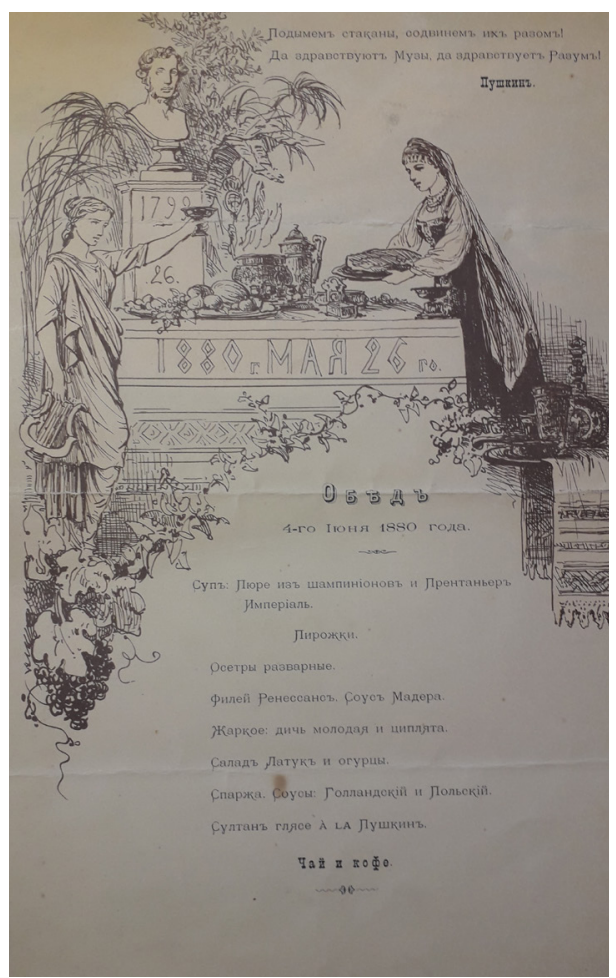

Илл. 7. Меню обеда в честь празднования дня рождения А. С. Пушкина.

Рис. К. А. Трутовского. ОРФ ГЛМ. Ф. 81. Оп. 1. Ед. хр. 8 
Особенно следует отметить два документа, посвященных Пушкинскому празднику 5-8 июня 1880 г., - это билет Ф. М. Достоевского № 254 для входа на торжественное собрание Московского университета и меню обеда в честь открытия памятника А. С. Пушкину (см. Илл. 6-7). Отметим, что первоначальная датировка пригласительного билета - 26 мая 1880 г. - не случайно исправлена чернилами на 4 июня. Первый день праздника намечался на 26 мая 1880 г. - день 81-й годовщины со дня рождения поэта. Но в связи с кончиной императрицы Марии Александровны и объявленным государственным трауром торжества были перенесены. Согласно Летописи, 4 июня Достоевский обедал в трактире Тестова, 5-го - в гостинице, а думский торжественный обед состоялся уже 6 июня [Летопись: 427-429]. Оба документа, наряду с многочисленными газетными откликами и воспоминаниями о Пушкинском празднике, позволяют ощутить, насколько торжественно и масштабно было обставлено это событие.

В фонде есть документы Ф. М. Достоевского малого формата: это визитные карточки ${ }^{24}$ в количестве 60 шт., квитанция от 22 мая 1880 г. об отправ-

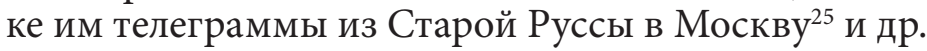

В фонде ГЛМ представлены также два документа, содержащих записи о Ф. М. Достоевском: один (копия записи в метрической книге) знаменует начало его жизненного пути, другой (свидетельство о смерти) - окончание.

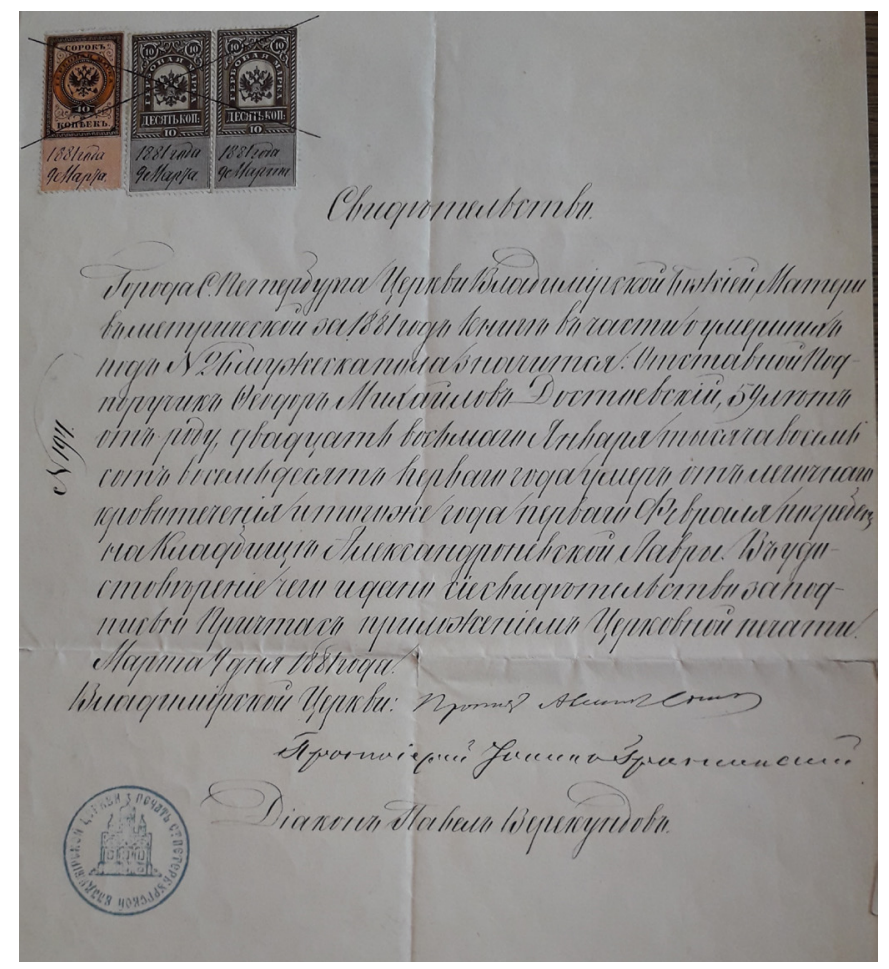

Илл. 8. «Свидетельство о смерти и погребении Ф. М. Достоевского, выданное причтом церкви Владимирской Божьей Матери в С.-Петербурге. 9 марта 1881» с гербовыми марками и церковной печатью. ОРФ ГЛМ. Ф. 81. Оп. 2. Ед. хр. 22. Л. 26 


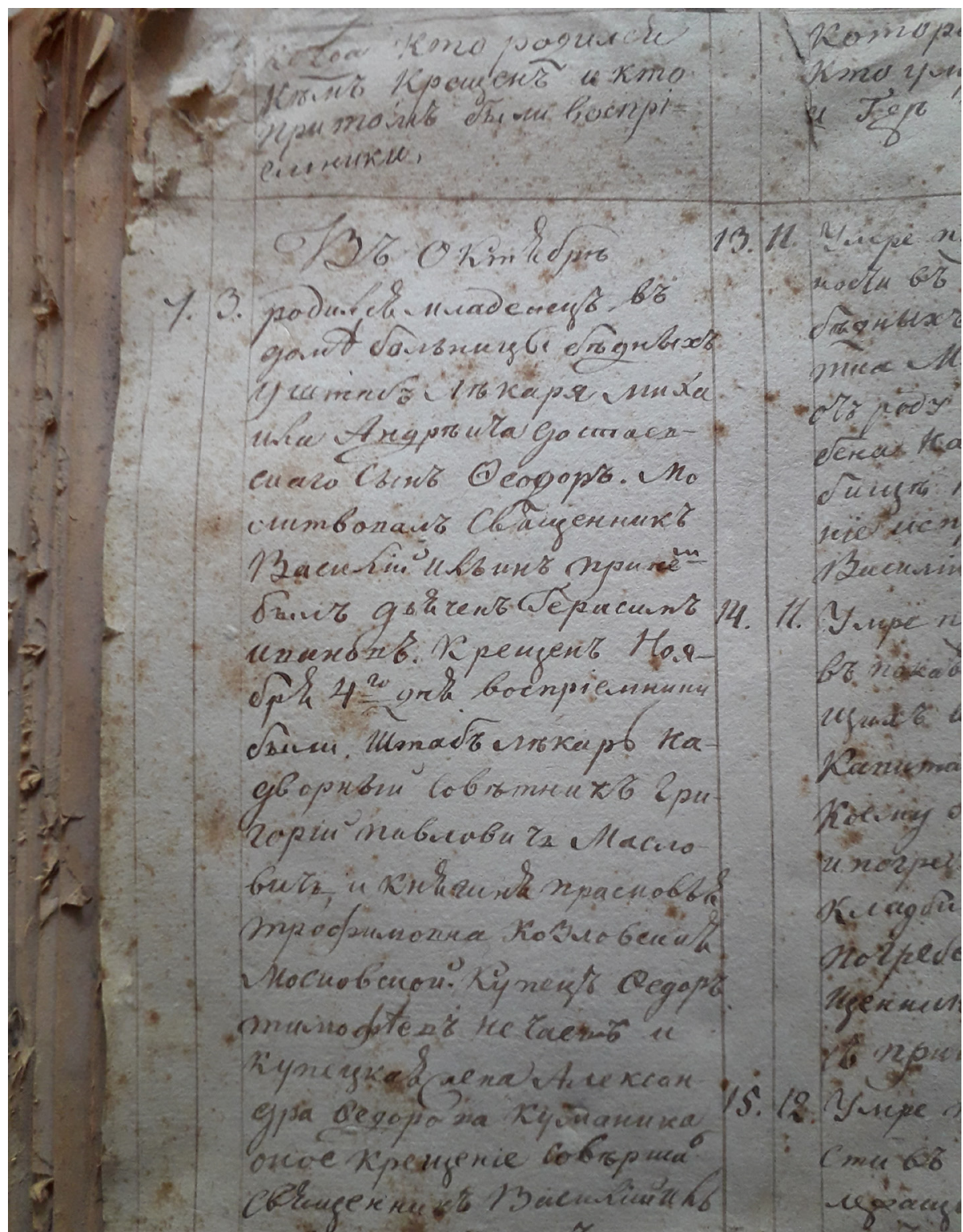

Илл. 9. Запись о рождении в «Книге для записи крещеных и отпетых в церкви Петра и Павла, что при больнице для бедных за 1814-1823 годы» (С. 148). Копия. Находится в постоянной экспозиции московской «Музей-квартиры Ф. М. Достоевского»

Со смертью писателя связана еще часть материалов фонда: последний номер газеты, прочитанный Ф. М. Достоевским («Новое время», № 1764) траурные листки с факсимиле подписи Ф. М. Достоевского, которые раздавались в день его похорон ${ }^{27}$; билет для входа в церковь Св. Духа в день отпевания 1 февраля 1881 г. $^{28}$ 
К визуальным материалам фонда относятся и некоторые документы, принадлежавшие родственному окружению писателя. Значительную часть составляют сведения об имущественно-хозяйственной деятельности А. Г. Достоевской: небольшие записки, письма делового характера разным корреспондентам $^{98}$, почтовые конверты ${ }^{30}$; ее визитные карточки в количестве двух штук ${ }^{31}$; визитные карточки посетительниц ${ }^{32}$; черновые записи расходов, связанных с издательской деятельностью в 1880 -е гг. ${ }^{33}$; книжка на покупку сахара $(1917)^{34}$ и др.

Следует отметить почтовые конверты на адрес А. Г. Достоевской из бюро газетных вырезок ${ }^{35}$, где содержится 15 документов (1880-1911). До конца жизни А. Г. Достоевская собирала отзывы о Ф. М. Достоевском из различных газет и журналов, пользуясь помощью сотрудников Бюро газетных вырезок. Фамилию одного из них обнаружила И. С. Андрианова в черновиках воспоминаний А. Г. Достоевской: «...весною 1914 г. <...> я увезла съ собою на люто для просмотра всп безчисленныя вырпзки изб газеть за весь годб, приготовл<енныя > для меня г. Клишевичем<ъ $>\{$ поставляем<ыя > мнгь агентомъ по вырпзк< $<a м z>\}^{2} »^{36}$. Его обязанности сводились к тому, чтобы просмотреть доступную ему текущую периодику, найти статьи о Ф. М. Достоевском, другие публикации с упоминанием его имени, вырезать их и отправить ей.

Часть материалов поступила от потомков Михаила и Андрея Достоевских, братьев писателя. Отметим патент М. М. Достоевского 1842 г. на чин прапорщика ${ }^{37}$, личные документы его сына Михаила (выписка из метрической книги о браке 1869 г. и свидетельство о причислении его семьи к дворянству $^{38}$, вид на жительство ${ }^{39}$ ) и его внучки Марии Михайловны Достоевской ${ }^{40}$. Один документ от 18 августа 1879 г., заверенный нотариусом, связан с делом Куманиных и представляет собой доверенность А. М. Достоевского, брата писателя, сыну Андрею Андреевичу на участие в разделе наследства $^{41}$. Есть также конверт письма с автографом Л. Ф. Достоевской, дочери писателя, своему кузену А. А. Достоевскому (1912) ${ }^{42}$.

В фонде достаточно широко представлена печатная продукция театров, связанная с постановками конца XIX - начала XX вв. произведений Ф. М. Достоевского на российской и зарубежной сценах. В делах №№ 60-82, 93, 95-96 (Ф. 81. Оп. 1) содержатся афиши, программы, брошюры выдающихся спектаклей, каждый из которых становился событием и вносил новое в сценическое прочтение Ф. М. Достоевского. Среди документов отметим программу спектакля 1914 г. «Николай Ставрогин» (МХT, реж. В. И. Немирович-Данченко $)^{43}$, в котором образ героя «Бесов» выразил трагическое предчувствие "разлома времен»; программу спектакля МХT 1917 г. «Село Степанчиково» (реж. В. И. Немирович-Данченко), где в заглавном

2) В фигурные скобки заключен вариант, вписанный А. Г. Достоевской над строкой. 
образе Фомы Опискина (исп. И. М. Москвин) современники узнавали черты Григория Распутина ${ }^{44}$. Афиши и программы спектакля «Идиот» ${ }^{45}$ (реж. Г. А. Товстоногов) в БДТ (1957) напоминают о легендарной постановке, которая внесла, по свидетельству историка театра Г. Лапкиной, «немало нового в изучение самого романа» [Лапкина: 324]. В числе этих документов программа спектакля «Петербургские сновидения» ${ }^{46}$ (реж. Ю. А. Завадский, 1972) в театре им. Моссовета, где режиссером предложено революционное для своего времени прочтение романа «Преступление и наказание», породившее горячие споры вокруг спектакля.

Иллюстративный ряд, хранящийся в изобразительном фонде ГЛМ и представляющий собой фотографии актеров в образах, сцены из спектаклей по Ф. М. Достоевскому, вкупе с афишами создают целостное впечатление о постановках. Рукописный и изобразительный фонды ГЛМ дополняют и обогащают друг друга. Коллекции изобразительного фонда ГЛМ насчитывает около двух тысяч единиц, которые представляют собой фотографии и портреты писателя, лиц из его окружения, его родственников и потомков, а также фотографии, связанные с историей увековечения его памяти. Необходимо отметить, что более чем на 50 фотографиях из собрания А. Г. Достоевской изображены неустановленные лица из окружения Достоевских. Решение проблемы атрибуции планируется с помощью введения фотографий в специальные компьютерные программы распознавания лиц, в которых используется метод чтения и сканирования изображений для поиска в различных базах данных и «фотобанках» людей второй половины XIX в.

В отличие от оригинальных визуальных материалов, большая часть текстовых документов фонда Ф. М. Достоевского рукописного отдела ГЛМ имеет характер «вторичных»: это оттиски научных публикаций; вырезанные или переписанные от руки газетные, журнальные статьи о Ф. М. Достоевском; перепечатки материалов к его биографии; материалы к истории музейновыставочной деятельности. В первую опись в дел №№ 11-59 включены отдельные статьи или оттиски статей с автографами, экслибрисами, дарственными надписями исследователей Ф. М. Достоевского разных лет - Н. Ф. Бельчикова, Л. П. Гроссмана, В. С. Нечаевой, Г. М. Фридлендера и др.; черновые рукописи Г. И. Чулкова; газетные публикации 1920-1930-х гг.; публикации по музейной и выставочной деятельности. Материалы о Ф. М. Достоевском не имеют разделения по тематике и сформированы по номинальному признаку. Отметим документы, связанные с историей Больницы для бедных в Москве ${ }^{47}$; Лазаревским кладбищем, местом захоронения матери писателя М. Ф. Достоевской и других родственников писателя ${ }^{48}$. Также в ГЛМ представлены воспоминания А. Е. Ризенкампфа о Ф. М. Достоевском ${ }^{49}$, материалы к биографии И. Н. Шидловского ${ }^{50}$ и С. Д. Яновского ${ }^{51}$. 
Во второй описи зарегистрированы собранные А. Г. Достоевской критические отзывы о Ф. М. Достоевском из газетных статей периода с 1846 по 1914 г. Эти материалы составляют обширную часть фонда. Систематизированные по хронологии, они представляют собой достаточно полную картину критических отзывов о Ф. М. Достоевском, на основе которых можно собирать количественные данные, выделяя в каждой статье ключевые слова и наблюдая за частотой их повторяемости. Формирование единых тематических групп позволит выйти к обобщениям о свойствах и особенностях восприятия творчества Ф. М. Достоевского его читателями-современниками.

\section{ПРИМЕЧАНИЯ}

* Исследование выполнено при финансовой поддержке РФФИ в рамках научного проекта № 18-012-90018 Достоевский.

1 Отдельные документы, связанные с биографией Ф. М. Достоевского и с историей увековечения его памяти, представлены также в Москве в Государственном архиве Российской Федерации, в Российском государственном военно-историческом архиве, в архиве Государственного исторического музея, в архивах других городов России.

2 См. об этом: [Андрианова].

ОРФ ГЛМ. Ф. 81. Оп. 2. Ед. хр. 128. 43 лл.

ОРФ ГЛМ. Ф. 81. Оп. 1. Ед. хр. 4.2 лл.

ОРФ ГЛМ. Ф. 81. Оп. 1. Ед. хр. 5.

ОРФ ГЛМ. Ф. 81. Оп. 1. Ед. хр. 1.

См.: Достоевский Ф. М. Полн. собр. соч.: в 30 т. Т. 292. Л.: Наука, 1986. С. 75.

ОРФ ГЛМ. Ф. 252. Оп. 1. Ед. хр. 1.3 лл.

ОРФ ГЛМ. Ф. 252. Оп. 1. Ед. хр. 2-3.

10 ОРФ ГЛМ. Ф. 75.

ОРФ ГЛМ. Ф. 81. Оп. 2. Ед. хр. 22. Лл. 5-6.

Там же. Лл. 1-4.

Там же. Лл. 7-8.

Там же. Лл. 16-22.

Там же. Л. 16 об.

Там же. Лл. 18-21.

Там же. Л. 22.

Там же. Лл. 23-25.

ОРФ ГЛМ. Ф. 81. Оп. 2. Ед. хр. 27. 21 лл.

20 Достоевский Ф. М. Полн. собр. соч.: в 30 т. Т. 28. Л.: Наука, 1986. С. 9.

21 Там же. С. 21.

22 ОРФ ГЛМ. Ф. 81. Оп. 2. Ед. хр. 13, 15, 17, 19.

23 ОРФ ГЛМ. Ф. 81. Оп. 2. Ед. хр. 26.

24 ОРФ ГЛМ. Ф. 81. Оп. 2. Ед. хр. 21.

25 ОРФ ГЛМ. Ф. 81. Оп. 2. Ед. хр. 18.

26 ОРФ ГЛМ. Ф. 81. Оп. 2. Ед. хр. 20.2 лл. ОРФ ГЛМ. Ф. 81. Оп. 2. Ед. хр. 23-25.

ОРФ ГЛМ. Ф. 81. Оп. 2. Ед. хр. 61. Л. 2.

29 ОРФ ГЛМ. Ф. 81. Оп. 2. Ед. хр. 97-100.

30 ОРФ ГЛМ. Ф. 81. Оп. 2. Ед. хр. 108. 
31 ОРФ ГЛМ. Ф. 81. Оп. 2. Ед. хр. 115.

32 ОРФ ГЛМ. Ф. 81. Оп. 2. Ед. хр. 110.

33 ОРФ ГЛМ. Ф. 81. Оп. 2. Ед. хр. 116.

34 ОРФ ГЛМ. Ф. 81. Оп. 2. Ед. хр. 130. 4 лл.

35 ОРФ ГЛМ. Ф. 81. Оп. 2. Ед. хр. 109.

36 См.: Достоевская А. Г. Воспоминания. Черновые варианты // РГАЛИ. Ф. 212.1.146. Л. 24.

37 ОРФ ГЛМ. Ф. 81. Оп. 1. Ед. хр. 120.

38 Аттестат Царскосельской женской гимназии, 1892 г.; свидетельство о записи в метрической книге 1878 г. о рождении и крещении, свидетельство о причислении к роду (1894-1920) // ОР ГЛМ. Ф. 81. Оп. 1. Ед. хр. 121.

39 ОРФ ГЛМ. Ф. 81. Оп. 1. Ед. хр. 122.

40 ОРФ ГЛМ. Ф. 81. Оп. 1. Ед. хр. 123, 124.

41 ОРФ ГЛМ. Ф. 81. Оп. 1. Ед. хр. 118. 2 лл.

42 ОРФ ГЛМ. Ф. 81. Оп. 1. Ед. хр. 96.

43 ОРФ ГЛМ. Ф. 81. Оп. 1. Ед. хр. 62.

44 ОРФ ГЛМ. Ф. 81. Оп. 1. Ед. хр. 63.

45 ОРФ ГЛМ. Ф. 81. Оп. 1. Ед. хр. 79. 2 лл.

46 ОРФ ГЛМ. Ф. 81. Оп. 1. Ед. хр. 80.2 лл.

47 ОРФ ГЛМ. Ф. 81. Оп. 1. Ед. хр. 127. 167 лл.

48 ОРФ ГЛМ. Ф. 81. Оп. 1. Ед. хр. 133-134.

49 ОРФ ГЛМ. Ф. 81. Оп. 1. Ед. хр. 11. 35 лл.

50 ОРФ ГЛМ. Ф. 81. Оп. 2. Ед. хр. 69. Лл. 16-17.

51 ОРФ ГЛМ. Ф. 81. Оп. 1. Ед. хр. 132.18 лл.

\section{СПИСОК ЛИТЕРАТУРЫ}

1. Андрианова И. С. «Музей памяти Ф. М. Достоевского»: история и перспективы проекта. - Петрозаводск: Изд-во ПетрГУ, 2013. - 192 с.

2. Достоевская А. Г. Воспоминания. 1846-1917. - М.: Бослен, 2015. - 768 с.

3. Коган Г. Ф. Черновой набросок к роману «Униженные и оскорбленные» // Ф. М. Достоевский: новые материалы и исследования. - М.: Наука, 1973. - С. 11-15. (Литературное наследство; т. 86).

4. Коган Г. Ф. Диплом из архива // Известия. - 1976. - 1 сентября.

5. Коган Г. Ф. Достоевский на Пушкинских вечерах Литфонда // Новые материалы по истории русской литературы: сб. науч. тр. - М.: Гос. Лит. музей, 1994. - С. 32-48.

6. Коган Г. Ф. Из истории московской коллекции: (поиски и находки) // Достоевский и мировая культура. Альманах № 14. - М., 2001. - С. 112-137.

7. Лапкина Г. Достоевский на советской сцене. 1917-1970 гг. // Достоевский и театр. - Л.: Искусство, 1983. - 510 с.

8. Побединский Ф. [Бережков Ф. Ф.] Ф. М. Достоевский. Письмо В. А. Алексееву // Голос минувшего на чужой стороне. - 1927. - № 5. - С. 197-201.

9. Пономарева Г. Музей-квартира Ф. М. Достоевского в Москве. - М.: Паломникъ, 2002. $-110 \mathrm{c}$. 
Anna V. Petrova

(Moscow, Russian Federation)

netochka-1@yandex.ru

\section{F. M. Dostoevsky in the Documents of the Manuscript Department of The Russian Literary History State Museum Named After V. I. Dahl}

Acknowledgments. The reported study was funded by RFBR, project number 18-012-90018 Dostoevsky.

Abstract. The article presents an overview of the materials about F. M. Dostoevsky from the collection of his wife A. G. Dostoevskaya, who in May 1906 gave them for eternal storage in Moscow. Since the middle of the 20th century the documents have been partially kept in the Manuscript Department of the State Museum of the history of Russian literature named after Vladmir Dahl (State Literary Museum). The most valuable are the letters of F. M. Dostoevsky and other visual materials related to the main events of the writer's life. All these documents have preserved the memory of the life of the great writer, the uniqueness of his personality. Text documents of the Fund systematically and fully represent newspaper criticism of F. M. Dostoevsky in the period from 1846 to 1914 and selectively, at the level of individual articles, the history of the study of the biography and work of the writer in the 20th century. The Dostoevsky Manuscript Fund is enriched with a plentiful collection of the Fund of visual documents, among others photographs, portraits of Fyodor Dostoevsky and persons from his entourage, collected by A. G. Dostoevskaya.

Keywords: F. M. Dostoevsky, collection of A. G. Dostoevskaya, The Russian Literature History State Museum Named After V. I. Dahl, handwritten materials, source studies

About the author: Petrova Anna V. - PhD in Philology, Senior Researcher of "Museum-apartment of F. M. Dostoevsky", The Russian Literary History State Museum Named After V. I. Dahl (State Literary Museum) (ul. Dostoevskogo 2, Moscow, 103030, Russian Federation)

Received: April 18, 2019

Date of publication: June 30, 2019

For citation: Petrova A. V. F. M. Dostoevsky in the Documents of the Manuscript Department of the Russian Literary History State Museum Named After V. I. Dahl. In: Neizvestnyy Dostoevskiy [The Unknown Dostoevsky], 2019, no. 2, pp.40-55. DOI: 10.15393/j10.art.2019.4101 (In Russ.)

\section{REFERENCES}

1. Andrianova I. S. «Muzey pamyati F. M. Dostoevskogo»: istoriya i perspektivy proekta ["The Dostoevsky Memorial Museum": History and Prospects of the Project]. Petrozavodsk, Petrozavodsk State University Publ., 2013. 192 p. (In Russ.)

2. Dostoevskaya A. G. Vospominaniya. 1846-1917 [Memoirs. 1846-1917]. Moscow, Boslen Publ, 2015. 768 p. (In Russ.)

3. Kogan G. F. A Rough Sketch for the Novel "Humiliated and Insulted". In: F. M. Dostoevskiy: Novye materialy i issledovaniya [F. M. Dostoevsky: New Materials and Researches]. Moscow, Nauka Publ., 1973, pp. 11-15 (Ser. “Literary Heritage”; vol. 86). (In Russ.)

4. Kogan G. F. Diploma From the Archive. In: Izvestiya, 1976, september 1. (In Russ.) 
5. Kogan G. F. Dostoevsky at the Pushkin Evenings of the Literary Fund. In: Novye materialy po istorii russkoy literatury [New Materials on the History of Russian Literature]. Moscow, State Literary Museum Publ., 1994, pp. 32-48. (In Russ.)

6. Kogan G. F. From the History of the Moscow Collection (Searches and Finds). In: Dostoevskiy i mirovaya kul'tura. Almanakh № 14 [Dostoevsky and World Culture. Almanac No. 14]. Moscow, 2001, pp. 112-137. (In Russ.)

7. Lapkina G. Dostoevsky on the Soviet Stage. 1917-1970. In: Dostoevskiy i teatr [Dostoevsky and the Theater]. Leningrad, Iskusstvo Publ., 1983. 510 p. (In Russ.)

8. Pobedinskiy F. [Berezhkov F. F.] F. M. Dostoevskiy. The Letter to Alekseev. In: Golos minuvshego na chuzhoy storone, 1927, no. 5, pp. 197-201. (In Russ.)

9. Ponomareva G. Muzey-kvartira F. M. Dostoevskogo v Moskve [F. M. Dostoevsky's Museum-Apartment in Moscow]. Moscow, Piligrim Publ., 2002. 110 p. (In Russ.) 